\title{
Uhl's anomaly
}

\author{
R. J. VECHT, D. J. S. CARMICHAEL, R. GOPAL, AND G. PHILIP \\ From the Departments of Cardiology and Pathology, St Mary's Hospital, London
}

SUMMARY Uhl's anomaly of the heart is a rare condition. Another well-documented case is presented with a review of the published reports outlining the main clinical features and the bad overall prognosis. Right atriotomy should be avoided if closure of the atrial septal defect is attempted.

In 1952, Uhl reported a previously undescribed congenital malformation of the heart. This consisted of an almost total absence of the myocardium of the right ventricle. In the same year, Castleman and Towne (1952) described the case of a woman with a paper-thin right ventricle the volume of which was estimated to be 5 times that of the left ventricle.

In both instances, the predominant feature was the very thin-walled and enlarged right ventricle; this was unlike the case previously reported by Osler as 'parchment heart' in which both ventricles were found to be extremely thin (Segall, 1950).

Few additional cases have since come to light (Taussig, 1960; Arcilla and Gasul, 1961; Reeve and Macdonald, 1964; Cumming et al., 1965; Neimann et al., 1965; Perrin and Mehrizi, 1965; Froment et al., 1968; Kinare et al., 1969; Aherne, 1973; Côté et al., 1973; Perez Diaz et al., 1973; French

Received for publication 4 August 1978
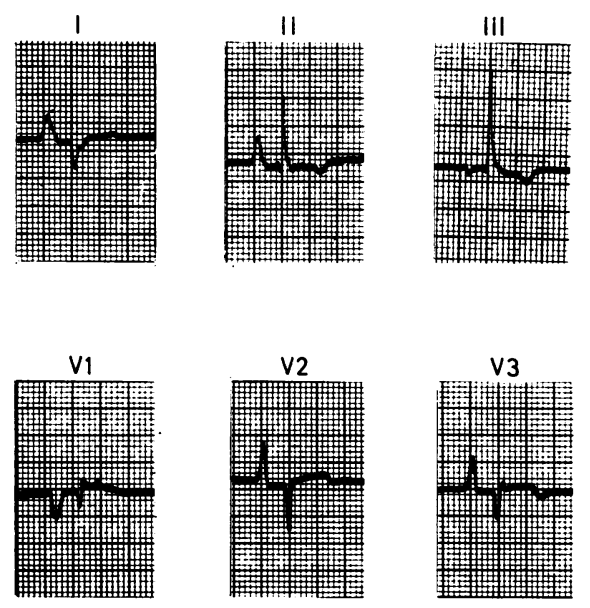

et al., 1975; Haworth et al., 1975) and we wish to present another patient with this rare condition.

\section{Case report}

A 19-year-old Maltese man was admitted for cardiac investigation. He was the youngest of a family of $9, \vec{\theta}$ all of whom were healthy. At the time of pregnancy $c$ his mother was aged 40 . Both pregnancy and parturition were uneventful. At 1 week he was cyanosed particularly on crying. At the age of 9 years he was more cyanosed, clubbed, and of a gracile build. The heart was 'quiet' to palpation and pulmonary closure was delayed. The haemoglobin was $15.4 \mathrm{~g} / \mathrm{dl}$. He grew to adult size, enjoying normal schooling and playing football until the age of 15 years. From then onwards he complained of dyspnoea and tiredness on exertion. He suffered from occasional chest pains and lost consciousness three times during physical effort. His haemoglobin had risen to $17.5 \mathrm{~g} / \mathrm{dl}$ and ectopic rhythm
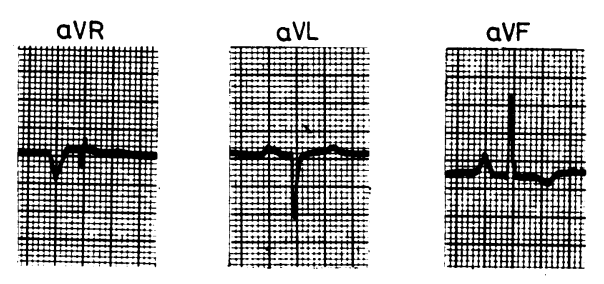

Fig. 1 Electrocardiogram showing right axis deviation, prominent $P$ waves in leads $I, I I$, and $V 2$ to V4, large negative $P$ waves in $V 1$, and $Q$ waves in $V 1$ to $V 4$. 
ECG

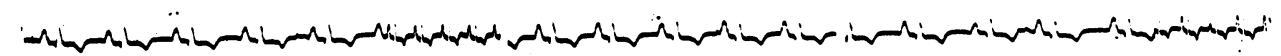

RA $\underset{v 10}{\operatorname{ar}} \overline{8}$

RV $20 / 12$

PA $2 q_{12} \overline{14}$

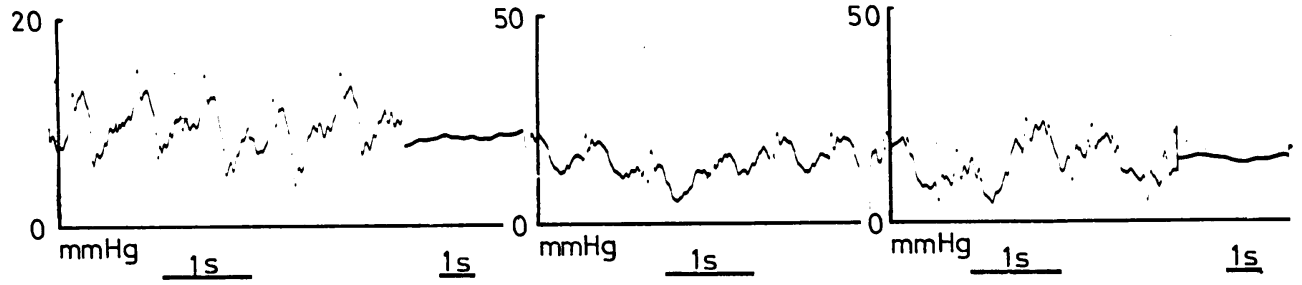

Fig. 2 Right-sided pressures showing the dominant a wave in the right atrium. This is transmitted to the low right ventricle and pulmonary artery pressures.

activity was also noted. A chest $x$-ray film showed an enlarged heart and the clinical diagnosis of Ebstein's disease was made (see Fig. 3a).

On admission, the jugular venous pressure was raised with a dominant $a$ wave. The cyanosis and clubbing were more evident and the haemoglobin was $23.4 \mathrm{~g} / \mathrm{dl}$, with a packed cell volume of 73 per cent.

1. Electrocardiography (Fig. 1) showed right axis deviation and Qr complexes in V2 to V4. There were tall $P$ waves in leads I, II, and V2 to V4, and deep inverted $P$ waves in V1 of greater amplitude than the ventricular complex. Echocardiography showed a dilated right ventricular cavity in com- parison with the much smaller left ventricle. The pulmonary valve was clearly seen to open during diastole.

Cardiac catheterisation disclosed arterial desaturation $(73 \%)$ with right atrial, right ventricular, and pulmonary arterial saturations ranging between 52 and 60 per cent. The pressures (Fig. 2) showed similar contours in the three right-sided areas. The dominant right atrial $a$ wave was transmitted into the low pressure right ventricle and pulmonary artery.

Endocardial potentials showed a normal transition of ventricular to atrial complexes, thus excluding a displaced tricuspid valve. This was

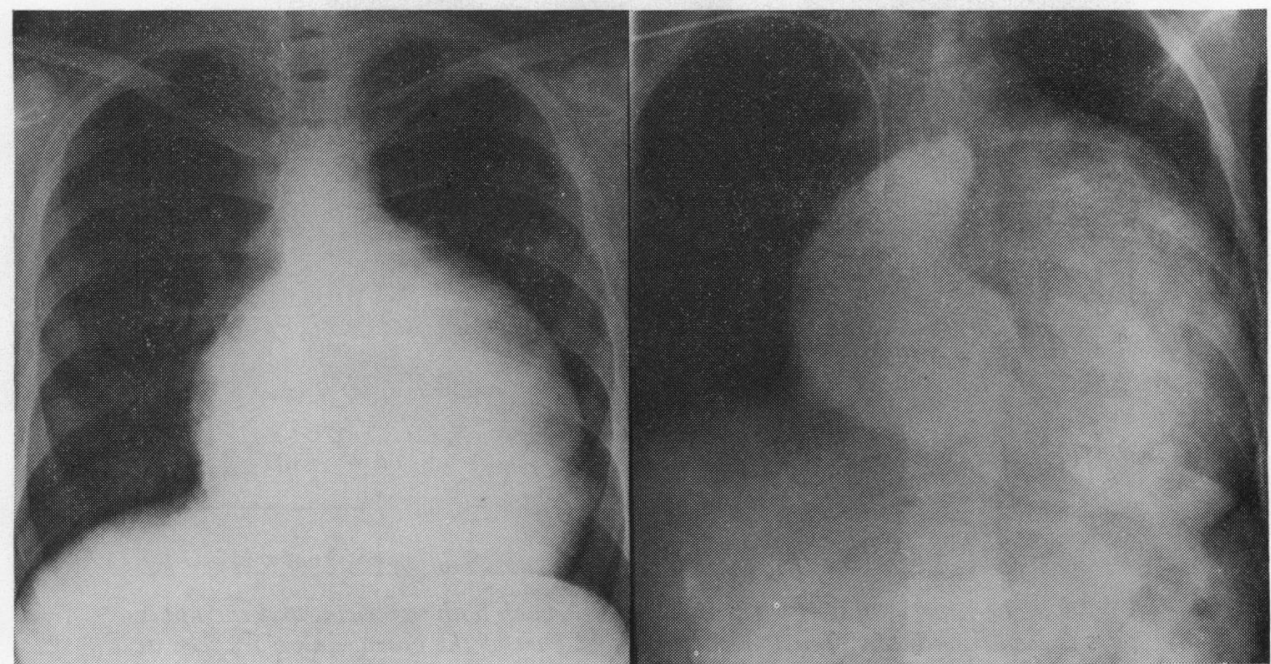

(a)

Fig. 3 (a) Plain chest x-ray film on the left. There is obvious cardiomegaly with pulmonary oligaemia. (b) On the right, contrast material filling the enlarged right atrium with normally placed tricuspid valve. 
confirmed by angiography (Fig. 3b). Contrast was seen to enter a conspicuously dilated right ventricle during atrial contraction and to stagnate within the right ventricle which did not appear to contract. There was no visible contrast in the left atrium.

As a result of these findings and the gradual deterioration of the patient it was felt that surgical closure of the presumed patent foramen ovale or atrial septal defect was indicated.

At operation a grossly dilated right ventricle was found showing paradoxical pulsation. The right atrium was relatively thick-walled and enlarged. Cardiopulmonary bypass with moderate hypothermia to $30^{\circ} \mathrm{C}$ was instituted and through a posteriorly placed right atriotomy a $3 \times 2 \mathrm{~cm}$ secundum atrial septal defect was closed with a continuous suture. Rewarming and right atrial closure were uneventful; total perfusion time was 40 minutes with aortic cross-clamping time of 10 minutes. Half an hour later, during closure of the chest wall, there was a sudden drop in arterial systolic pressure from 110 to $50 \mathrm{mmHg}$, with a

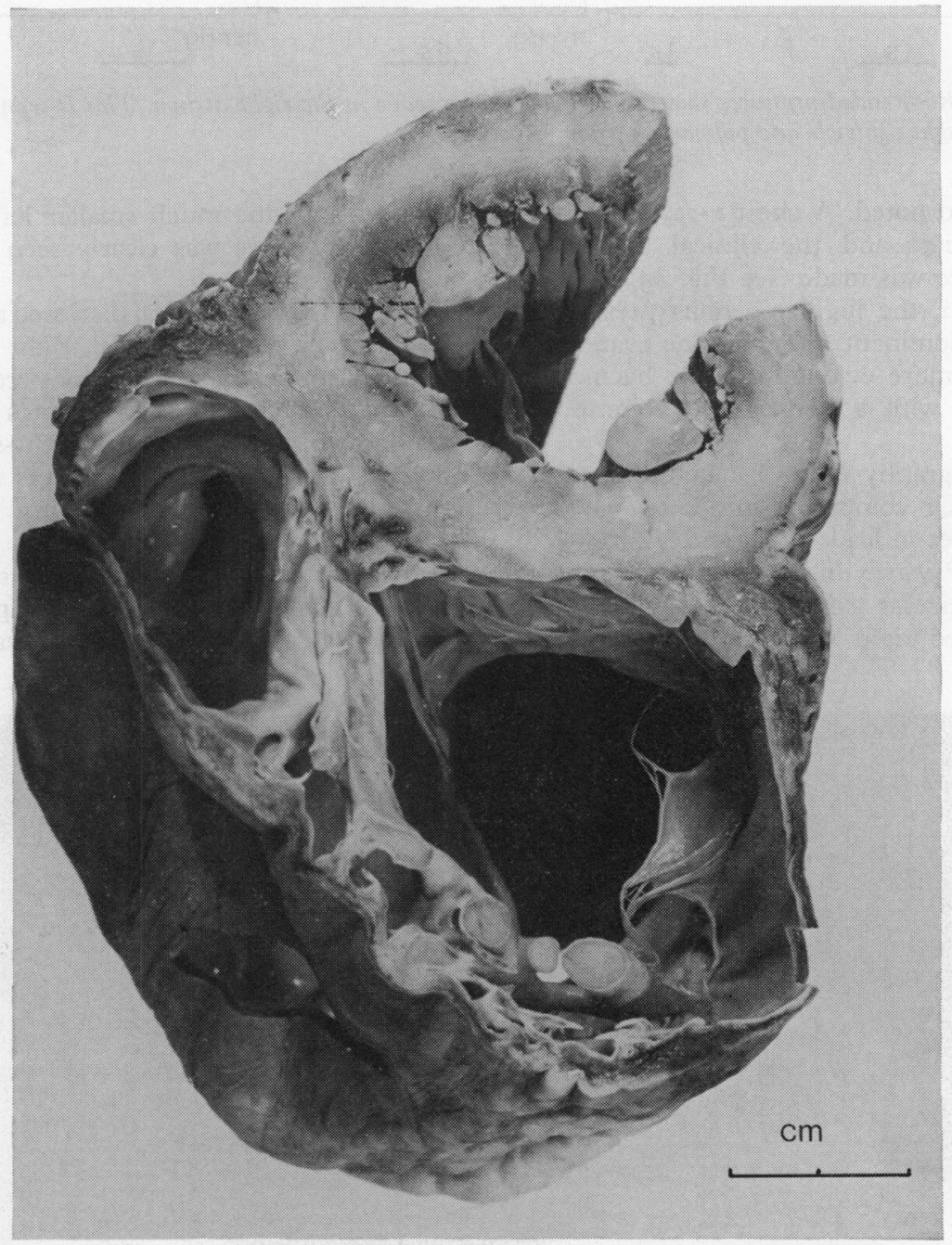

Fig. 4 The heart has been cut transversely through both ventricles and the upper part is seen from below. The left ventricle and part of the mitral valve are seen at the upper right. The remainder of the picture is occupied by the thin-walled and enormously dilated right ventricle, the cavity of which is crossed by a moderator band. The pulmonary outflow tract is seen in the centre left of the picture and the normally placed tricuspid valve leaflets and papillary muscles at the lower right. 
change in rhythm to atrial fibrillation. Despite several attempts at DC conversion, the arrhythmia persisted and the left ventricle then fibrillated. Further resuscitative measures failed.

\section{NECROPSY FINDINGS}

The heart weighed $435 \mathrm{~g}$. Its venous and arterial connections were normal and the ductus arteriosus

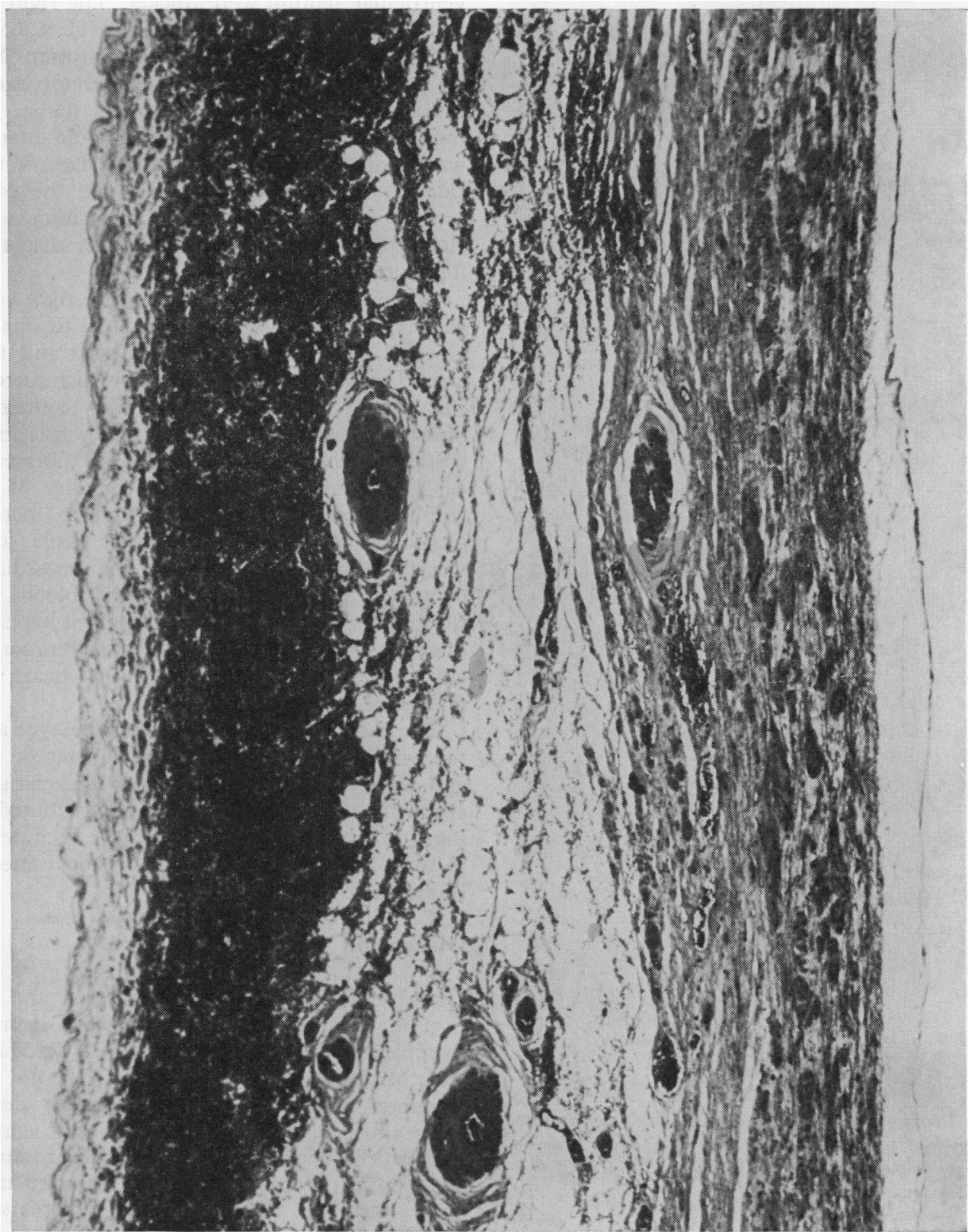

Fig. 5 A section of the free wall of the right ventricle showing (from left to right) pericardium and fatty epicardial tissue with areas of operative haemorrhage and several thick-walled blood vessels. This is in direct contact with the thickened endocardium with no intervening muscular layer. The muscle bundles visible to the extreme right of the picture are hypertrophied endocardial smooth muscle and are not myocardial fibres. 


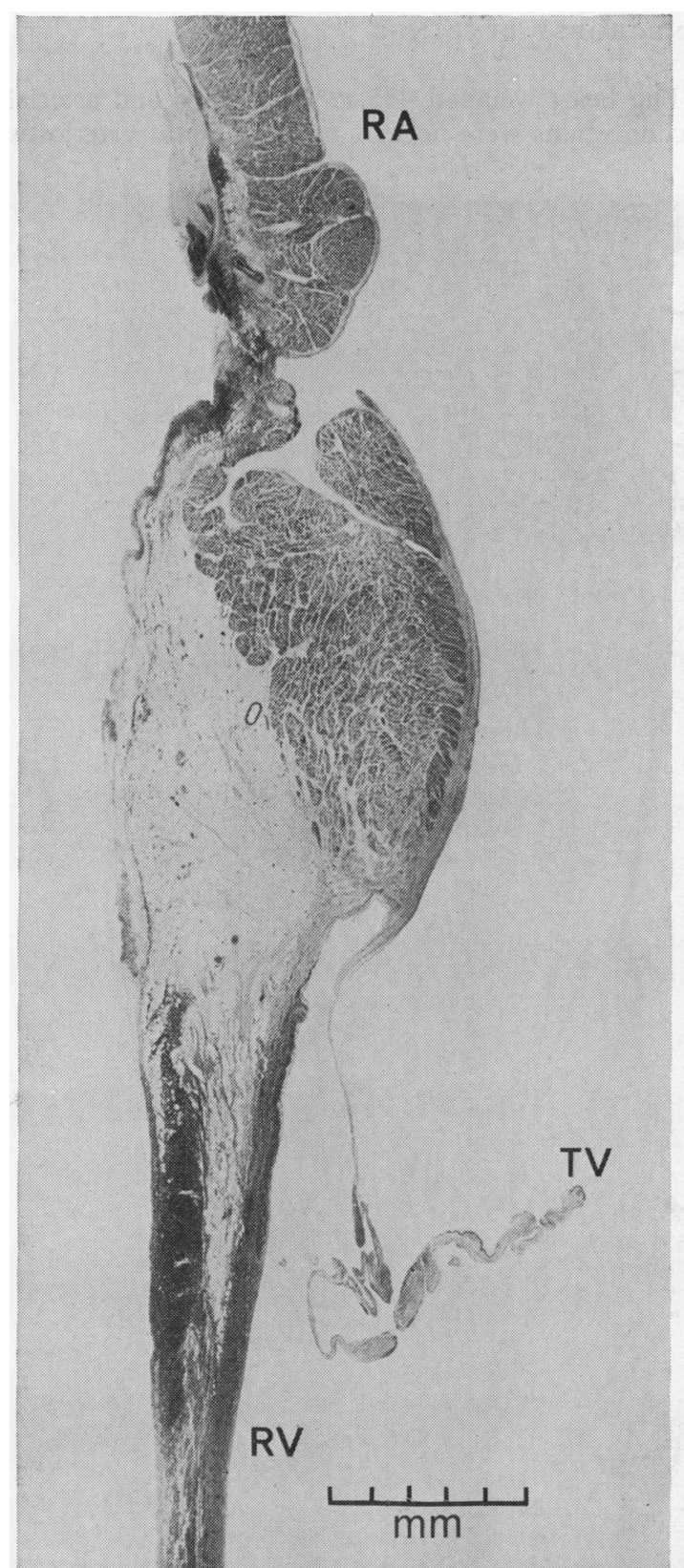

Fig. 6 A section through the tricuspid valve ring showing the greatly hypertrophied right atrium $(R A)$ above and the thin right ventricular wall $(R V)$ below. The tricuspid valve $(T V)$ is normally sited.

was closed. The right atrium was a large chamber $(7 \times 6 \times 5 \mathrm{~cm})$ with a hypertrophied and trabeculated wall which measured up to $5 \mathrm{~mm}$ in thickness. The tricuspid valve leaflets were normally positioned and were inserted into a fibrous and muscular ring $15 \mathrm{~cm}$ in circumference. Just below this, the right $ᄃ$ ventricle decreased abruptly in thickness and the $\overrightarrow{\vec{s}}$ greater part of its free wall measured only $2 \mathrm{~mm}$ in thickness, though the areas adjacent to the inter- $\frac{}{0}$ ventricular septum were thicker. The right ventricular cavity was enormously dilated $(11 \times 8 \times 7 \mathrm{~cm}) \stackrel{ه}{ه}$ and was lined by thickened endocardium (Fig. 4). Its cavity was crossed by a moderator band and several narrower bands of fibrous tissue, but no $\vec{\circ}$ mural thrombus was present. The pulmonary valve $\overrightarrow{\vec{\omega}}$ was normal. The chambers and valves of the left $\stackrel{\sigma}{\omega}$ side of the heart were normal and the coronary arteries were normal in size and position, with the $A$ right coronary artery slightly smaller than the left. $\vec{\sigma}$ The sutures were all intact.

Microscopy of the free wall of the right ventricle or showed cardiac muscle to be limited to small areas 을 close to the interventricular septum and the tri- cuspid valve. The thin membrane which surrounded $\subseteq$ the greater part of the chamber contained no $\Phi$ striated muscle and from within outwards consisted $\overrightarrow{0}$ of (i) endothelium, (ii) a thickened fibrous endo- $\widehat{c}$ cardium containing numerous bundles of hypertrophied smooth muscle cells and an increase in elastic tissue, (iii) fatty epicardial tissue, and (iv) visceral pericardium (Fig. 5). The epicardial layer contained prominent thick-walled blood vessels. $\frac{\mathrm{D}}{\mathrm{D}}$ Sections from the right atrium showed hypertrophy $\stackrel{2}{\Rightarrow}$ of the myocardium (Fig. 6) but no alteration in the $\frac{O}{3}$ endocardium. Sections from the left heart showed no special features.

The endocardial changes were of the type associated with long-standing cardiac dilatation (Fisher $\overparen{\mathbb{D}}$ and Davies, 1958). The muscular thickening of the epicardial vessels can probably be attributed to the $\frac{\sigma}{5}$ same cause since similar vessels have been described in the adventitial layer of thoracic aortic aneurysms (Pomerance et al.s 1977).

\section{Discussion}

Uhl's anomaly is rarely encountered and should No not be confused with isolated right ventricular hypoplasia (Sackner et al., 1961; Van der Hauwaert $\mathcal{N}$ and Michaelson, 1971; Haworth et al., 1975). W Common to all cases of Uhl's anomaly described is the extremely thin and enlarged right ventricular wall which contains little if any myocardium. This $\stackrel{\oplus}{\Phi}$ is in contrast with the small right ventricular cavity and normal wall thickness found in cases of right ventricular hypoplasia. From the Table reviewing $\underset{\mathbb{D}}{\stackrel{0}{ }}$ the published cases of Uhl's anomaly it can be $\frac{?}{\mathbb{D}}$ seen that the sex incidence was equal and that ages $\propto$ at presentation ranged from 1 day to 57 years. Of the 18 cases reviewed here cyanosis was noticeable in 
able Salient features in patients with Uhl's anomaly: review of published reports

\begin{tabular}{|c|c|c|c|c|c|c|c|c|c|c|c|c|}
\hline uthor & $\begin{array}{l}\text { Year of } \\
\text { publication }\end{array}$ & $\begin{array}{l}\text { Agel } \\
\text { sex }\end{array}$ & $\begin{array}{l}\text { Presenting } \\
\text { features }\end{array}$ & Other signs & $\begin{array}{l}\text { Age and cause } \\
\text { of death }\end{array}$ & $\begin{array}{l}\text { Post } \\
\text { mortem }\end{array}$ & $R V$ & $R A$ & $L V$ & $\begin{array}{l}\text { Coronary } \\
\text { arteries }\end{array}$ & $\begin{array}{l}\text { y } A S D / \\
F O\end{array}$ & Surgery \\
\hline hl & 1952 & $\begin{array}{l}7 / 12 \\
F\end{array}$ & Tachypnoea & $\begin{array}{l}\text { Cyanosis, } \\
\text { oedema, } \\
\text { cardiomegaly }\end{array}$ & $\begin{array}{l}8 / 12 \\
\text { CCF }\end{array}$ & Yes & $\begin{array}{l}\text { Thin, } \\
\text { large } \\
\text { thrombus }\end{array}$ & Large & $\mathbf{N}$ & $\mathbf{N}$ & None & None \\
\hline $\begin{array}{l}\text { astleman } \\
\text { and Towne }\end{array}$ & 1952 & $\begin{array}{l}24 y \\
F\end{array}$ & $\begin{array}{l}\text { Dyspnoea, } \\
\text { ectopic beats, } \\
\text { atrial flutter, } \\
\text { AV block, } \\
\text { chest pain }\end{array}$ & $\begin{array}{l}\text { Raised JVP, } \\
\text { oedema, } \\
\text { cardiomegaly }\end{array}$ & ${ }_{\mathrm{CCF}}^{25 \mathrm{y}}$ & Yes & $\begin{array}{l}\text { Thin, } \\
\text { large } \\
\text { thrombus }\end{array}$ & $\begin{array}{l}\text { Large } \\
\text { Thin }\end{array}$ & $\mathbf{N}$ & $\mathbf{N}$ & None & None \\
\hline aussig & 1960 & $\begin{array}{l}6 \mathrm{y} \\
\mathrm{M}\end{array}$ & $\begin{array}{c}\text { Dyspnoea, } \\
\text { reduced } \\
\text { exercise } \\
\text { tolerance }\end{array}$ & $\begin{array}{l}\text { CCF, } \\
\text { cyanosis, } \\
\text { cardiomegaly, } \\
1^{\circ} \text { AV block }\end{array}$ & $\begin{array}{l}\text { 6y } \\
\text { postop }\end{array}$ & Yes & $\begin{array}{c}\text { Normal } \\
\text { size }\end{array}$ & Large & $\mathbf{N}$ & $\mathbf{N}$ & ASD & $\begin{array}{l}\text { Pott's, } \\
\text { later closed }\end{array}$ \\
\hline $\begin{array}{l}\text { rcilla and } \\
\text { Gasul }\end{array}$ & 1961 & $\begin{array}{l}5 / 12 \\
M\end{array}$ & Tachypnoea & Cardiomegaly & $\begin{array}{l}12 / 12 \\
\text { CCF }\end{array}$ & Yes & $\begin{array}{l}\text { Large } \\
\text { paper-thin }\end{array}$ & Large & Large & ? & FO & None \\
\hline $\begin{array}{l}\text { eeve and } \\
\text { Macdonald }\end{array}$ & 1964 & $\begin{array}{l}47 y \\
F\end{array}$ & $\begin{array}{l}\text { Dyspnoea, } \\
\text { SVT, } \\
\text { chest pain }\end{array}$ & $\begin{array}{l}\text { Cyanosis, } \\
\text { cardiomegaly }\end{array}$ & $\begin{array}{l}47 y \\
\text { subarachnoid } \\
\text { haemorrhage }\end{array}$ & Yes & Large & Large & $\mathbf{N}$ & $\mathbf{N}$ & FO & None \\
\hline umming et al. & 1965 & $\begin{array}{l}7 / 12 \\
F\end{array}$ & Dyspnoea & $\begin{array}{l}\text { Cyanosis, } \\
\text { cardiomegaly }\end{array}$ & $\begin{array}{l}7 / 12 \\
\text { postop }\end{array}$ & Yes & Large & Large & $\mathbf{N}$ & $\mathbf{N}$ & FO & Glenn \\
\hline eimann et al. & 1965 & $\begin{array}{l}4 d \\
F\end{array}$ & Tachypnoea & $\begin{array}{l}\text { Cyanosis, } \\
\text { cardiomegaly, } \\
\text { hepatomegaly }\end{array}$ & $\begin{array}{l}5 \mathrm{~d} \\
\mathrm{y}\end{array}$ & Yes & $\begin{array}{r}\text { Large } \\
\text { thin }\end{array}$ & Large & LVH & $\mathbf{N}$ & ASD & None \\
\hline $\begin{array}{l}\text { zrrin and } \\
\text { Mehrizi }\end{array}$ & 1965 & $\begin{array}{l}10 / 12 \\
M\end{array}$ & Oedema & $\begin{array}{l}\text { Cyanosis, } \\
\text { raised JVP, } \\
\text { cardiomegaly }\end{array}$ & $\begin{array}{l}13 / 12 \\
\mathrm{CCF}\end{array}$ & Yes & $\begin{array}{l}\text { Large } \\
\quad \text { paper-thin }\end{array}$ & $\begin{array}{l}\text { Large } \\
\text { Thin }\end{array}$ & $\mathbf{N}$ & $\mathbf{N}$ & None & None \\
\hline ould et al. & 1967 & $\begin{array}{l}57 y \\
M\end{array}$ & Chest pain & $\begin{array}{l}\text { Hepatomegaly, } \\
\text { no cardio- } \\
\text { megaly }\end{array}$ & $\begin{array}{l}66 y \\
\text { leukaemia, } \\
\text { renal failure }\end{array}$ & Yes & $\begin{array}{l}\text { Large } \\
\text { paper-thin }\end{array}$ & $\mathbf{N}$ & LVH & $\mathbf{N}$ & None & None \\
\hline roment et al. & 1968 & $\begin{array}{l}19 \mathrm{y} \\
M\end{array}$ & Dyspnoea & Cardiomegaly & $\begin{array}{l}\text { 19y } \\
\text { postop }\end{array}$ & Yes & $\begin{array}{l}\text { Large } \\
\text { thin } \\
\text { thrombus }\end{array}$ & $\begin{array}{l}\text { Large } \\
2 \text { cusps }\end{array}$ & $\mathbf{N}$ & $\mathbf{N}$ & None & Exploratory \\
\hline , & ” & $\begin{array}{l}26 y \\
M\end{array}$ & VT & Cardiomegaly & $\begin{array}{l}26 y \\
\text { arrhythmia }\end{array}$ & Yes & $\begin{array}{l}\text { Large } \\
\text { thin } \\
\text { thrombus }\end{array}$ & $\begin{array}{l}\text { Large } \\
2 \text { cusps }\end{array}$ & $?$ & $?$ & $?$ & None \\
\hline inare et al. & 1969 & $\begin{array}{l}5 y \\
F\end{array}$ & Dyspnoea & $\begin{array}{l}\text { Cyanosis } \\
\text { cardiomegaly }\end{array}$ & $\begin{array}{l}5 y \\
\text { postop }\end{array}$ & Yes & $\begin{array}{l}\text { Large } \\
\text { paper-thin }\end{array}$ & Large & $\mathbf{N}$ & $\mathbf{N}$ & None & Exploratory \\
\hline herne & 1973 & $\begin{array}{l}7 / 52 \\
\mathrm{~F}\end{array}$ & Oedema & $\begin{array}{l}\text { CCF, } \\
\text { cardiomegaly }\end{array}$ & $10 / 12$ & Yes & $\begin{array}{l}\text { Large } \\
\text { thin }\end{array}$ & Large & $\mathbf{N}$ & $\mathbf{N}$ & None & None \\
\hline ôté et al. & 1973 & $\begin{array}{l}19 h \\
F\end{array}$ & Tachypnoea & $\begin{array}{l}\text { Cyanosis, } \\
\text { gallop, } \\
\text { cardiomegaly, } \\
\text { hepatomegaly }\end{array}$ & $\begin{array}{l}2 \frac{1}{2} \mathrm{~d} \\
\text { respiratory } \\
\text {, distress }\end{array}$ & Yes & $\begin{array}{r}\text { Large } \\
\text { thin }\end{array}$ & $\begin{array}{r}\text { Large } \\
\text { thin }\end{array}$ & $\mathbf{N}$ & $\mathbf{N}$ & ASD & None \\
\hline erez Diaz et al. & 1973 & $\begin{array}{l}4 / 12 \\
M\end{array}$ & Dyspnoea & $\begin{array}{l}\text { Cyanosis, } \\
\text { CCF, } \\
\text { cardiomegaly }\end{array}$ & CCF & Yes & $\begin{array}{c}\text { Large } \\
\text { thin }\end{array}$ & Large & $\mathbf{N}$ & $\mathbf{N}$ & None & None \\
\hline rench et al. & 1975 & $\begin{array}{l}14 y \\
F\end{array}$ & $\begin{array}{l}\text { Diminished } \\
\text { exercise } \\
\text { tolerance, } \\
\text { AV dissocia- } \\
\text { tion, nodal } \\
\text { rhythm }\end{array}$ & $\begin{array}{l}\text { Cyanosis, } \\
\text { cardiomegaly }\end{array}$ & Alive & - & Large & Large & Large & ? & ASD & ASD closed \\
\hline Iaworth et ai. & 1975 & $\begin{array}{l}1 \mathrm{~d} \\
\mathbf{M}\end{array}$ & & $\begin{array}{l}\text { Cyanosis, } \\
\text { cardiomegaly, } \\
\text { hepatomegaly }\end{array}$ & $\begin{array}{l}4 \text { days } \\
\text {, not known } \\
\text { y }\end{array}$ & Yes & $\begin{array}{c}\text { Large } \\
\text { thin }\end{array}$ & Large & $?$ & $?$ & FO & None \\
\hline Techt et al. & $\begin{array}{l}\text { present } \\
\text { report }\end{array}$ & $\begin{array}{l}19 y \\
M\end{array}$ & $\begin{array}{l}\text { Dyspnoea, } \\
\text { chest pain, } \\
\text { ectopics }\end{array}$ & $\begin{array}{l}\text { Cyanosis, } \\
\text { cardiomegaly }\end{array}$ & $\begin{array}{l}19 y \\
\text { postop }\end{array}$ & Yes & $\begin{array}{l}\text { Large } \\
\text { paper-thin }\end{array}$ & Large & $\mathbf{N}$ & $\mathbf{N}$ & ASD & ASD closed \\
\hline
\end{tabular}

2V, right ventricle; RA, right atrium; LV, left ventricle; ASD, atrial septal defect; FO, foramen ovale; CCF, congestive cardiac failure; N, normal; JVP, ugular venous pressure; SVT, supraventricular tachycardia; LVH, left ventricular hypertrophy; VT, ventricular tachycardia.

12 cases. Four patients had patent foramen ovales and 5 others had atrial septal defects. In some cases cyanosis was present without an obvious intracardiac shunt.

Right ventricular thrombus was found in 4 cases and arrhythmias were described in 6 patients. Four patients complained of chest pain and effort syncope was encountered in 2 cases. Non-specific systolic murmurs were frequently audible. Seventeen of the patients succumbed and only 1 survived operation (closure of atrial septal defect).

Electrocardiography characteristically showed large $P$ waves in lead $\mathrm{II}_{\text {s }}$ with diminished right ventricular potentials. Chest radiography invariably demonstrated an enlarged cardiac shadow. Specific echocardiographic features consisted of an enlarged 
right ventricular cavity, delayed tricuspid valve closure, and diastolic pulmonary valve opening, allowing differentiation from Ebstein's anomaly which closely resembles this condition.

Additional defects have been described in association with Uhl's anomaly. They include dysplasia of the tricuspid valve, pulmonary atresia, and persistent ductus arteriosus (Neimann et al., 1965; Côté et al., 1973; Haworth et al., 1975). These rare defects were seen infrequently.

The pulmonary circulation in Uhl's anomaly is entirely maintained by right atrial contraction. This is recognisable at angiography and from the similar pressure contours seen in the right-sided chambers. The tricuspid valve is not displaced as in Ebstein's syndrome; the left ventricle and the left atrium are usually normal as are the coronary arteries. Fibroelastosis was seen in a few cases. Surgical management has included Glenn and Potts procedures with unacceptable results. It has been suggested that before operation right heart function should be assessed by temporary balloon occlusion of the defect (Van der Hauwaert and Michaelson, 1971) though this is not always possible (Haworth et al., 1975) and was not attempted in our case. Closure of an atrial septal defect may offer some benefit and was performed in our case, though death ensued after the onset of atrial fibrillation. It is assumed that this was related to the right atrial incision and we suggest that the surgical approach might be via a right ventricular incision with closure of the atrial septal defect through the tricuspid valve. Thus an atrial incision would be avoided.

We wish to thank Dr E. M. M. Besterman and $\mathrm{Mr}$ L. L. Bromley for allowing us to study their patient.

\section{References}

Aherne, W. A. (1973). Uhl's anomaly (abstract). Archives of Disease in Childhood, 48, 160.

Arcilla, R. A., and Gasul, B. M. (1961). Congenital aplasia or marked hypoplasia of the myocardium of the right ventricle (Uhl's anomaly). Fournal of Pediatrics, 58, 381-388.

Castleman, B., and Towne, V. W. (1952). Case record of the Massachusetts General Hospital No. 38201. New England Fournal of Medicine, 246, 785-790.

Côté, M., Davignon, A., and Fouron, J. C. (1973). Congenital hypoplasia of right ventricular myocardium (Uhl's anomaly) associated with pulmonary atresia in a newborn. American fournal of Cardiology, 31, 658-661.
Cumming, G. R., Bowman, J. M., and Whytehead, L. (1965). Congenital aplasia of the myocardium of the right ventricle $C$ (Uhl's anomaly). American Heart fournal, 70, 671-676.

Fisher, E. R., and Davies, E. R. (1958). Observations concerning the pathogenesis of endocardial thickening. 0 American Heart fournal, 56, 553-561.

French, J. W., Baum, D., and Popp, R. J. (1975). Echo- $\frac{\bar{\sigma}}{\bar{\omega}}$ cardiographic findings in Uhl's anomaly. Demonstration of diastolic pulmonary valve opening. American fournal of $\stackrel{\mathbb{Q}}{\varrho}$ Cardiology, 36, 349-353.

Froment, R., Perrin, A., Loire, R., and Dalloz, C. J. (1968). ఓ Ventricule droit papyracé du jeune adulte par dystrophie $\vec{O}$ congénitale. Archives des Maladies du Coeur et des Vaisseaux, 61, 477-503.

Gould, L., Guttman, A. B., Carrasco, J., and Lyon, A. F. (1967). Partial absence of right ventricular musculature. A congenital lesion. American fournal of Medicine, 42, 636-641.

Haworth, S. G., Shinebourne, E. A., and Miller, G. A. H. (1975). Right to left interatrial shunting with normal right ventricular pressure. British Heart fournal, 37, 386-391. O

Kinare, S. G., Panday, S. R., and Deshmukh, S. M. (1969). ఠా Congenital aplasia of the right ventricular myocardium 은 (Uhl's anomaly). Diseases of the Chest, 55, 429-431.

Neimann, N., Pernot, C., and Rauber, G. (1965). Aplasie du $\vec{c}$ myocarde du ventricule droit (ventricule droit papyracé congénitale). Archives des Maladies du Coeur et des Vaisseaux, $\overparen{\overparen{D}}$ 58, 421-430.

Perez Diaz, L., Quero Jimenez, M., Moreno Granados, F., $\vec{\oplus}$ Perez Martinez, V., and Merino Batres, G. (1973). Congenital absence of myocardium of right ventricle: Uhl's anomaly. British Heart fournal, 35, 570-572.

Perrin, E. V., and Mehrizi, A. (1965). Isolated free wall hypoplasia of the right ventricle. American fournal of $\bar{\partial}$ Diseases of Children, 109, 558-566.

Pomerance, A., Yacoub, M. H., and Gula, G. (1977). The $\frac{\mathrm{O}}{\mathbb{D}}$ surgical pathology of thoracic aortic aneurysms. Histo- $\frac{\varrho}{-}$ pathology, 1, 257.

Reeve, R., and Macdonald, D. (1964). Partial absence of the 3 right ventricular musculature-partial parchment heart. $\bar{F}$ American Fournal of Cardiology, 14, 415-419.

Sackner, M. A., Robinson, M. J., Jamison, W. L., and Lewis, D. H. (1961). Isolated right ventricular hypoplasia $\vec{D}$ with atrial septal defect or patent foramen ovale. Circulation, 24, 1388.

Segall, H. N. (1950). Parchment heart (Osler). American Heart fournal, 40, 948-950.

Taussig, H. (1960). Congenital Malformation of the Heart: II, Specific Malformations, pp. 138-145. Commonwealth Fund, Harvard University Press, Cambridge, Massachusetts.

Uhl, H. S. M. (1952). Previously undescribed congenital $D$ malformation of the heart: almost total absence of the myocardium of the right ventricle. Bulletin of the fohns Hopkins Hospital, 91, 197-205.

Van der Hauwaert, L. G., and Michaelson, M. (1971). N Isolated right ventricular hypoplasia. Circulation, 44, 466-474. 요

Requests for reprints to Dr R. J. Vecht, Cardiac? Department, St Mary's Hospital, Praed Street, 0 London W2 1NY. 